\title{
Seasonal changes in oocyte development, growth and population size distribution of Percilia gillissi and Trichomycterus areolatus in the Itata basin, Chile
}

\section{Cambio estacionales en el desarrollo de oocitos, crecimiento y distribución de talla poblacional de Percilia gillissi y Trichomycterus areolatus en la cuenca del río Itata, Chile}

\author{
Gustavo Chiang ${ }^{1,3^{*}}$, Kelly R. Munkittrick ${ }^{1}$, Mark E. McMaster ${ }^{2}$, Felipe Tucca ${ }^{3}$, M. Fernanda \\ SaAvedra ${ }^{3}$, Andrea AncalaF ${ }^{4}$, Juan F. Gavilán ${ }^{4}$, Luis Unzueta and Ricardo Barra ${ }^{3}$ \\ ${ }^{1}$ Canadian Rivers Institute and Department of Biology, University of New Brunswick, Saint John, Canada. \\ ${ }^{2}$ Environment Canada, National Water Research Institute, Burlington, ON L7R 4A6, Canada. \\ ${ }^{3}$ Aquatic Systems Unit, EULA-Chile Environmental Sciences Centre, University of Concepción, Chile. \\ ${ }^{4}$ Department of Cellular Biology, Faculty of Biological Sciences, University of Concepción, Chile \\ *gchiang@udec.cl
}

\begin{abstract}
There is scarce basic biological data on native freshwater fish species from Chile and next to zero on growth, gonad development and reproduction, which are critical for the purposes of the conservation of their natural populations. Seasonal analysis of sub-individual (oocyte development) and population (length frequency, growth rates) endpoints in Trichomycterus areolatus and Percilia gillissi were evaluated from February 2007 to January 2008. Oocyte development has a marked seasonality for $P$. gillissi, with mature eggs in October and declining frequency of mature oocytes into January. For $T$. areolatus we found some mature eggs in July, with highest number of mature eggs in October, coincident with previous data on maximum gonad size. Both species showed a multiple spawning reproductive strategy, with a long spawning season starting in spring to early summer. Increased numbers of juveniles were observed during mid-summer for $P$. gillissi, and during the end of the summer and beginning of autumn for T. areolatus. Juveniles had a higher growth coefficient (K) (0.56-0.38 mm month-1) than adults $(0.29-0.15 \mathrm{~mm}$ month-1), and almost all juveniles in the population reached maturity before the spring ( $>50 \mathrm{~mm}$ for T areolatus and $>40 \mathrm{~mm}$ for $P$. gillissi) and were incorporated into the population as a new recruitment cohort. Knowledge of the seasonal variability of these individual and population level responses can help better understand the biology of the species, and simultaneously improve the management and conservation of freshwater biota in Chile.
\end{abstract}

KeYwords: Seasonal cycles, native fish Chile, oocyte development, multiple spawning reproductive strategy, population size-structure.

\section{RESUMEN}

Existen escasos datos de biología básica sobre las especies de peces nativas chilenas de agua dulce y casi ninguno en sobre el crecimiento, el desarrollo gonadal y reproducción, que son fundamentales para los propósitos de la conservación de sus poblaciones naturales. El análisis estacional de los parámetros sub-individuales (desarrollo de oocitos) y poblacionales (frecuencia de tallas y tasa de crecimiento) en Trichomycterus areolatus y Percilia gillissi fueron evaluados entre febrero de 2007 y enero de 2008.El desarrollo de los oocitos posee una marcada estacionalidad en $P$. gillissi con oocitos maduros en octubre y una disminución de estos estados maduros hacia enero. En T. areolatus encontramos oocitos maduros en Julio, pero con una mayor abundancia durante octubre, coincidente con datos previos de máximo desarrollo de la gónada. Ambas especies mostraron una estrategia reproductiva de desoves multiples, con una temporada de desove que comienza en primavera hasta principios de verano. Ambas especies evidencian un mayor número de juveniles durante mediados de la estación estival ( $P$. gillissi), finales de la estación estival ( $T$. areolatus) y principios de otoño, con un número decreciente hacia primavera. Los juveniles tienen un coeficiente de crecimiento $(\mathrm{K})$ mayor $(0.56-0.38 \mathrm{~mm}$ mes-1) comparados con los adultos (0.29-0.15 mm mes-1), y antes de primavera prácticamente todos los individuos en la población alcanzan la madurez ( $>50 \mathrm{~mm}$ for $T$ areolatus and $>40 \mathrm{~mm}$ for $P$. gillissi) y los juveniles son incorporados a la población en una nueva 
fase de reclutamiento. El conocimiento de la variabilidad estacional de estas respuestas individuales (desarrollo de oocitos) y poblacionales (frecuencia de tallas, tasas de crecimiento) puede ayudarnos a un mejor entendimiento de la biología de las especies, y simultáneamente mejorar el manejo y conservación de la biota dulceacuícola.

Palabras clave: ciclos estacionales, peces nativos chilenos, desarrollo de oocitos, estrategia de desoves múltiples, estructura de talla poblacional.

\section{INTRODUCTION}

There are many seasonal changes in individual fish and fish populations that might affect their sensitivity to environmental stress, and affect the sustainability of fish populations. Changes in gonad size, for example, are a consequence of physiological changes in sex steroid production and gonad development, which are ultimately, a consequence of previous biochemical and neuroendocrine changes at lower levels of organization. Serious changes in individual endpoints such as gonadal growth, have the potential to cause changes in the reproduction of individuals and population dynamics of the species. Changes at low levels of biological organization due to environmental stressors (Munkittrick et al. 1992; McMaster et al. 1991; Van der Kraak et al. 1992; Parrott et al. 2004), can also lead to impaired reproduction and sustainability of natural populations (Yeom \& Adams 2007).

At higher levels of organization, seasonal changes in size structure reflect important information about population dynamics, and reflect changes in reproductive performance, growth, and recruitment that will also affect population sustainability over longer temporal scales. Considerations into the relationship between the reproductive output and the resulting growth of the population is crucial to understanding of how fish populations will respond to sustained perturbations (Lowerre-Barbieri et al. 2011). Any such consideration depends on a clear understanding of the life-cycle dynamics of the population, from the production of viable eggs, through all processes that affect the probability of survival and maturation (Jakobsen et al. 2009). Knowledge of the seasonal variability of these individual responses can help us better understand how effects can occur, and simultaneously to improve the design of aquatic monitoring programs to detect change, with adequate statistical design incorporating this variability and seasonality (Munkittrick et al. 2009).

Chilean isolation from the rest of the continent has resulted in the existence of extremely unique species (Ruiz \& Berra 1994). This situation is clearly reflected in the low number of freshwater fish species in Chile, represented by 11 families, 17 genera and 44 species, with $40 \%$ of these species classified as endangered (Dyer 2000; Habit et al. 2006). The latter is particularly relevant when considering that $80 \%$ of the species in Chile are endemic, with high retention of primitive features, low diversity, small body size and adaptation to high gradient streams and fluctuating flows (Campos et al. 1993; Ruiz \& Berra 1994; Vila et al., 1999; Dyer 2000). The end result is in a unique group of freshwater fish, with high biogeographic and conservation value. However, there are important gaps in knowledge of their systematic, distribution and basic biology (Habit et al. 2006). Two of the most abundant fish species, with a larger geographic distribution in central-south Chilean basins are two small bodied fish: Trichomycterus areolatus Valencienes 1846 (Trichomycteridae, common name: Bagre: maximum reported length: $15 \mathrm{~cm}$; Arratia 1983) being found from the Coquimbo $\left(30^{\circ} \mathrm{S}\right)$ to the Los Lagos $\left(43^{\circ} \mathrm{S}\right)$ region (Arratia 1981; Dyer 2000) and Percilia gillissi Girard, 1854 (Percilidae, common name: Carmelita; maximum reported length: $9 \mathrm{~cm}$; Ruiz \& Marchant 2004) present from the Aconcagua valley $\left(32^{\circ} \mathrm{S}\right)$ to the Los Lagos region $\left(41^{\circ} \mathrm{S}\right)$ (Arratia et al. 1981; Zunino et al. 1999; Dyer 2000). Despite their large distribution, there is still limited knowledge of their basic biology. Both species live mainly in rhitron like zones of the river with shallow riffle and rapid habitats with $T$. areolatus highly associated with the substrates, while $P$. gillissi is a midwater dweller. Both species have a similar diet composed by benthic macroinvertebrates (Duarte et al. 1971; Ruiz 1994; Habit et al. 1998). Reproductive data for T. areolatus provided by Manriquez et al. (1988) and Habit et al. (2005) are coincident in describing their spawning season (Mid-spring to early-summer), but with differences in the estimation of fertile adults. There is a lack of consistent data on the reproductive biology of the Percilia genus, but for the congeneric species (P. irwini) spawning is estimated to occur in late winter and early spring, between August and November (Habit \& Belk 2007). Recently, we have assessed seasonal changes in metabolic and reproductive parameters such as gonadosomatic indices (GSI) for both species and described the macroscopic development of the gonad, along with identifying the size at first maturity (Chiang et al. 2011a). Despite one study describing the different stages of oocyte maturation for T. areolatus (Huaquin et al. 2002), there is nothing published for $P$. gillissi. There is also no data on seasonal development of oocytes for either species and on the temporal growth of individuals in the population. The main objectives of this work were to 1) study female reproduction by analyzing the seasonal development of the oocyte, 2) describe seasonal population size distribution and 3 ) estimate population growth rates for both juvenile and adult size classes. 


\section{MATERIALS AND METHODS}

\section{Study area}

The Itata basin is located in Chile's Biobío region between $35^{\circ}$ and $37^{\circ} \mathrm{S}$ with a surface area of $11,200 \mathrm{~km}^{2}$ and a length of the Itata river about $195 \mathrm{~km}$; the maximum elevation of the basin is at the Nevados del Chillan volcano (3213 m.a.s.l). According to several authors the discharge ranges from $240-750 \mathrm{~m}^{3} / \mathrm{s}$ in winter months to $<20 \mathrm{~m}^{3} / \mathrm{s}$ during the summer (DGA 2004; Dussaillant 2009). The watershed is comprised of three sub-basins: the Nuble, Diguillín and Itata, containing the Cholguán, Nuble, Chillan, Diguillín, Cato, Lonquén and Itata rivers (Dussaillant 2009). The two selected fish species, $T$. areolatus and $P$. gillissi are the most abundant fish species through the entire basin (Habit \& Ortiz 2009), especially dominant in the middle zone of the watershed where these studies were conducted. Three sites were selected for the collection of individuals; all sites were upstream the confluence of the Nuble and Itata rivers. The sites included two locations on the Itata River (S1, 36 $42^{\prime} 17,21^{\prime \prime} \mathrm{S} 72^{\circ} 26^{\prime} 47,04^{\prime \prime} \mathrm{W}$; S2, 36 $41^{\prime} 40,13^{\prime \prime} \mathrm{S}$ $72^{\circ} 26^{\prime} 47,04^{\prime \prime} \mathrm{W}$ ), and one site on the Nuble River (S3, $36^{\circ} 38^{\prime} 30,00^{\prime \prime} \mathrm{S}, 72^{\circ} 27^{\prime} 12,64^{\prime \prime} \mathrm{W}$ ) (Fig 1).

\section{Fish capture and sampling}

The fish were captured monthly between February 2007 and January 2008 (except for September) using a backpack electrofishing unit (Halltech Electrofisher, Canada) and a block seine $(6 \mathrm{~mm}$ mesh) in riffles $(0.2-0.3 \mathrm{~m} / \mathrm{s}, 0.2-0.4$ $\mathrm{m}$ depth) with boulder-cobble bedrock (approximately 15 $\mathrm{cm}$ diameter) and/or shallow riffles (0.1-0.2 $\mathrm{m} / \mathrm{s}, 0.1-0.4$ $\mathrm{m}$ depth) with cobble $(15 \mathrm{~cm}$ diameter) and stone bedrock. Most of the fishes were measured for length $( \pm 0.1 \mathrm{~mm})$ and weight $( \pm 0.01 \mathrm{~g})$, and released back to the river. According to previous unpublished data we had, we monthly sacrificed by spinal severance fish above $35 \mathrm{~mm}$ total length to obtain gonad samples, determine sex and for female histology.

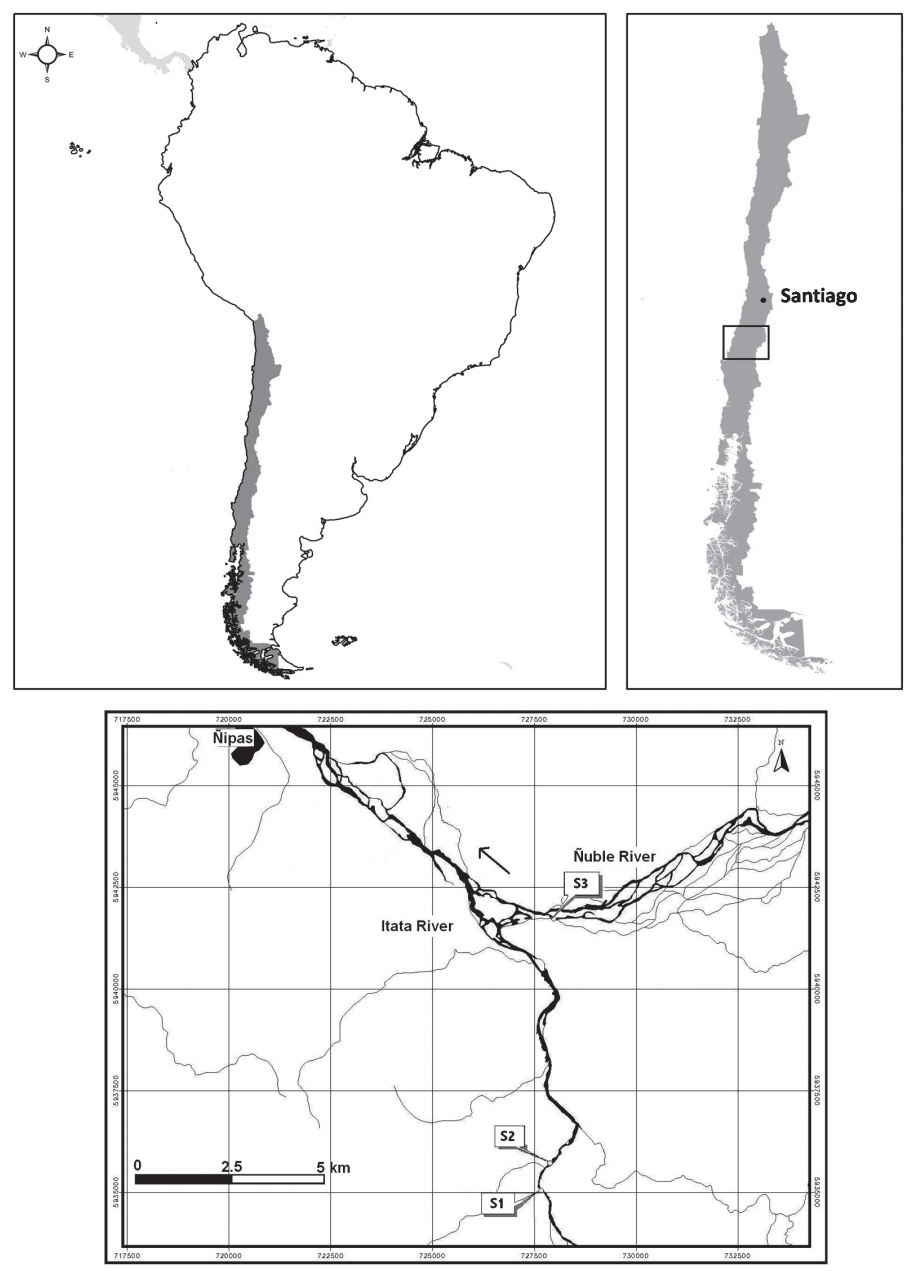

FIGURE 1. Seasonal reference sampling sites in Itata basin for recollection of T. areolatus and P. gillissi (S1-S3).

Figura 1. Sitios de muestreo estacional en la Cuenca del Itata durante la recolección de T. areolatus and P. gillissi (S1-S3). 
A total of 1848 individuals (909 for P. gillissi and 938 for $T$. areolatus) were collected and seasonal population size structure was assessed according to Pauly \& Morgan (1987). All length measurements were put into $2 \mathrm{~mm}$ size class intervals and analyzed using the FiSAT software package (FAO-ICLARM Fish Stock Assessment Tool). The ELEFAN I K-value scan routine was used with fixed starting and maximum length values for the whole length range. Juveniles were sorted from adults, and the "best" curve was fit to the set of length-frequency data, allowing calculation of K (von Bertalanffy growth model's growth rate coefficient) for each group.

Ovaries were collected from sampled fish and set in Bouin solution $(48 \mathrm{~h})$, then washed in $70 \%$ alcohol, three times for $15 \mathrm{~min}$. The tissue was subsequently dehydrated with a series of ethanol solutions (70-99\%) and chloroform, then twice infiltrated in liquid paraffin at $58{ }^{\circ} \mathrm{C}$ for $2 \mathrm{~h}$, then embedded in paraffin at room temperature $\left(16^{\circ} \mathrm{C}\right)$ for $24 \mathrm{~h}$. The embedded tissue was sectioned (thickness $7 \mu \mathrm{m}$ ) and stained with a solution of hematoxylin and eosin $(0.5 \%)$. A total of 524 ovaries were sampled for $P$. gillissi and 568 for $T$. areolatus. The proportion of oocytes of the various stages for the different months of sampling were analyzed using a minimum of 3 slides per ovary and the distinct maturation stages assigned according to a modified scale for Trichomycterus areolatus (Huaquin et al. 2002) and Percilia gillissi (modified from Quiroz 2006; Ancalaf 2008) (Table 1). Gonad Somatic Index (GSI) for sexually mature fish was modified from Chiang et al. (2010).

\section{Statistical analysis}

Due to this study's seasonal design, the analyses examined data for sex and species separately between sites during the period of gonad maturation. Due to the absence significant differences between the three reference sites, data were pooled and presented here for seasonal comparisons. Changes between months were assessed using an analysis of variance (ANOVA, $\mathrm{p}<0.05$; Systat (C11.0).

\section{RESULTS}

\section{Female gonad histology}

\section{Trichomycterus areolatus}

Only individuals $>54 \mathrm{~mm}$ total length (range $29-97.3 \mathrm{~mm}$ ) contained mature gonads in female $T$. areolatus. There were four states of maturity in the oocytes from the early winter period (June) to the early summer (January) (Fig. 2A and 2B). Seasonally, this species showed immature oocytes (Stage I and II), throughout their gonadal maturation cycle. Immature oocytes peaked in abundance in February and were minimal between June to October $\left(\mathrm{F}=8.208_{(10)} \mathrm{p}<0.001\right)$. Oocytes in intermediate stages of maturity (Stage III) were present at abundances less than 5\% in February, increased between July-October with levels often exceeding 25\%, then declined in January $\left(\mathrm{F}=11.753_{(10)}, \mathrm{p}<0.001\right)$. While the appearance of vitellogenic oocytes (Stage IV) occurs in June, the maximum number of vitellogenic oocytes occurs between October and November $\left(\mathrm{F}=7.851_{(6)}, \mathrm{p}<0.001\right)$, declining rapidly thereafter (Fig. 2B).

\section{Percilia gillissi}

Over a range of total length (23.1-91.6 mm), females of $P$. gillissi $>43 \mathrm{~mm}$ total length had ovaries with developing oocytes in all stages of maturity. There were no differences between sites in the development or the occurrence of oocytes in the ovaries of $P$. gillissi (Stage I and II $\mathrm{F}=0.146_{(2)}, \mathrm{p}=0.869$; Stage III $\mathrm{F}=0.690_{(2)} \mathrm{p}=0.503$, Stage IV F $=0.983_{(2)}, \mathrm{p}=0.377$, Stage V F=0.625 ${ }_{(2)}, \mathrm{p}=0.539$ ). Immature oocytes were observed during every month of collection along with a marked seasonality in the frequency of oocytes in all stages of maturity $\left(\mathrm{F}=6.604_{(10)}, \mathrm{p}<0.001\right.$, Fig 3A). Seasonally, there is a decrease in the frequency of oocytes in primary states of development (Stage I and II) from March $(>95 \%)$ to October $(<25 \%)$, and then increase in abundance within the ovary towards the summer period (Fig 3A and 3B). The previtellogenic (Stage III) and vitellogenic (Stage IV) oocytes are present throughout the year, with abundances that increased gradually from autumn to spring, whereas mature oocytes (Stage V) were visible since October, with highest frequencies between October and November $\left(\mathrm{F}=5.862_{(3)}, \mathrm{p}=0.002\right)$ reduced numbers in January and mature oocytes were not observed after this month (Fig. 3A).

\section{Seasonal Population Size Structure}

Trichomycterus areolatus

The size frequency distributions for the populations of catfish did not differ between sites throughout the study $\left(\mathrm{F}=1.593_{(2)}, \mathrm{p}=0.476\right)$, and all sites were pooled within month. Seasonally, there was an increase in the frequency of smaller sized fish from early summer (December), with two cohorts of individuals with different size distributions observed from December to early autumn (April). After this date, the size distribution becomes more homogeneous, with larger individuals in November compared to the months of December through to April $\left(\mathrm{F}=14.899_{(10)}, \mathrm{p}<0.001\right)$ (Fig. $4 \mathrm{~A})$. By separating the population into juveniles $(<54 \mathrm{~mm})$ and adults $(>54 \mathrm{~mm})$, no differences in the total length of adults in any month was observed $\left(\mathrm{F}=1.422_{(10)}, \mathrm{p}=0.212\right)$, but juveniles showed a significant increase in size from late summer to the spring period $\left(\mathrm{F}=4.00_{(10)}, \mathrm{p}>0.001\right)$. Growth coefficient values $\left(\mathrm{K} \mathrm{mm} \mathrm{month}^{-1}\right)$ for the whole population size distribution is $0.29 \mathrm{~mm} \mathrm{month}^{-1}$, but individuals $<54 \mathrm{~mm}$ reach values $>1.3$ times higher $\left(0.38 \mathrm{~mm} \mathrm{month}^{-1}\right)$, while individuals sexually active demonstrate a decrease in $\mathrm{K}$ values $\left(0.15 \mathrm{~mm} \mathrm{month}^{-1}\right)$ (Table 2$)$. 
Seasonal gonad development, growth and size structure dynamics of two freshwater fish from Chile: Gustavo CHIANG ET AL.

TABle 1. Oocyte development table for Percilia gillissi and Trichomycterus areolatus.

TABLa 1. Tabla de Desarrollo de oocitos para Percilia gillissi y Trichomycterus areolatus.

\begin{tabular}{|c|c|c|c|c|c|}
\hline Stage & & $\begin{array}{c}\text { Characteristics of oocyte } \\
\text { surface envelope }\end{array}$ & General appereance & Yolk & Nucleoli \\
\hline $\begin{array}{l}\text { Immature } \\
\text { with Primary } \\
\text { Growth }\end{array}$ & I y II & $\begin{array}{l}\text { A simple prefollicular cell } \\
\text { envelope }\end{array}$ & $\begin{array}{l}\text { Spherical cell. } \\
\text { Ooplasma highly } \\
\text { basophilic. Cortical } \\
\text { alveoli present. }\end{array}$ & N.O. & $\begin{array}{l}\text { Arranged on } \\
\text { the periphery of } \\
\text { the nucleus and } \\
\text { associated with the } \\
\text { inner face of the } \\
\text { nuclear envelope. }\end{array}$ \\
\hline Previtelogenic & III & $\begin{array}{l}\text { A simple follicular cells } \\
\text { envelope }\end{array}$ & $\begin{array}{l}\text { Ovoid cell. Ooplasm } \\
\text { of irregular aspect } \\
\text { due to the onset of } \\
\text { yolk incorporation. }\end{array}$ & $\begin{array}{l}\text { Starting yolk } \\
\text { micropinocytosis. }\end{array}$ & $\begin{array}{l}\text { Arranged on } \\
\text { the periphery of } \\
\text { the nucleus and } \\
\text { associated with the } \\
\text { inner face of the } \\
\text { nuclear envelope. } \\
\text { Comparatively higher } \\
\text { proportion. }\end{array}$ \\
\hline Vitelogenic & IV & $\begin{array}{l}\text { Oocyte thicker cover. } \\
\text { Composed by two layers } \\
\text { (zona radiata). } \\
10 \text { - } 38 \mu \mathrm{m} \text { thick. }\end{array}$ & $\begin{array}{l}\text { Ovoid cell. Ooplasm } \\
\text { irregular and sponge- } \\
\text { like due to the high } \\
\text { incorporation of yolk. } \\
\text { Nucleus shifted to } \\
\text { the periphery and } \\
\text { irregularly shaped. }\end{array}$ & $\begin{array}{c}\text { Active yolk } \\
\text { micropinocytosis. } \\
\text { Numerous granules } \\
\text { begin to coalescence. }\end{array}$ & N.O. \\
\hline Mature & $\mathbf{V}$ & $\begin{array}{l}\text { Thicker zona radiata. } \\
\text { Theca cells differenciated. } \\
20-88 \mu \mathrm{m} \text { thick }\end{array}$ & $\begin{array}{l}\text { Ovoid cell of } \\
\text { maximum growth and } \\
\text { development }\end{array}$ & $\begin{array}{l}\text { Homogeneous, large } \\
\text { flowing yolk mass }\end{array}$ & N.O. \\
\hline
\end{tabular}

Trichomycterus areolatus ${ }^{b}$

\begin{tabular}{|c|c|c|c|c|c|}
\hline $\begin{array}{l}\text { Immature and } \\
\text { Previtellogenic }\end{array}$ & I y II & $\begin{array}{l}\text { A simple follicular cell } \\
\text { envelope. }\end{array}$ & $\begin{array}{c}\text { Spherical cell. } \\
\text { Ooplasma highly } \\
\text { basophilic. Nucleus is } \\
\text { central with mild PAS } \\
\text { positive reaction. }\end{array}$ & N.O. & $\begin{array}{l}\text { Arranged on } \\
\text { the periphery of } \\
\text { the nucleus and } \\
\text { associated with the } \\
\text { inner face of the } \\
\text { nuclear envelope }\end{array}$ \\
\hline Vitellogenic & III & $\begin{array}{c}\text { Zona radiata composed } \\
\text { by two layers, with a PAS } \\
\text { positive reaction. }\end{array}$ & $\begin{array}{l}\text { Increase in size. The } \\
\text { nucleus moves to the } \\
\text { periphery and the cell } \\
\text { boundary becomes } \\
\text { irregular. }\end{array}$ & $\begin{array}{l}\text { Active yolk } \\
\text { accumulation. }\end{array}$ & $\begin{array}{l}\text { Large numbers of } \\
\text { nucleoli arranged in } \\
\text { the inner edge of the } \\
\text { karyotheca. }\end{array}$ \\
\hline Mature & IV & $\begin{array}{l}\text { Thiner Zona radiata with } \\
\text { a prismatic follicular } \\
\text { epithelium. }\end{array}$ & $\begin{array}{l}\text { Spherical cell. } \\
\text { Nucleus is in } \\
\text { the process of } \\
\text { disgregation, is finally } \\
\text { no longer observed }\end{array}$ & $\begin{array}{l}\text { Globular aspect of } \\
\text { the yolk, with some } \\
\text { zones PAS positive and } \\
\text { negative reaction }\end{array}$ & N.O. \\
\hline
\end{tabular}

${ }^{a}$ modified from Quiroz (2006); and Ancalaf (2008)

${ }^{\mathrm{b}}$ modified from Huaquin et al. (2002).

N.O. Not Observed 

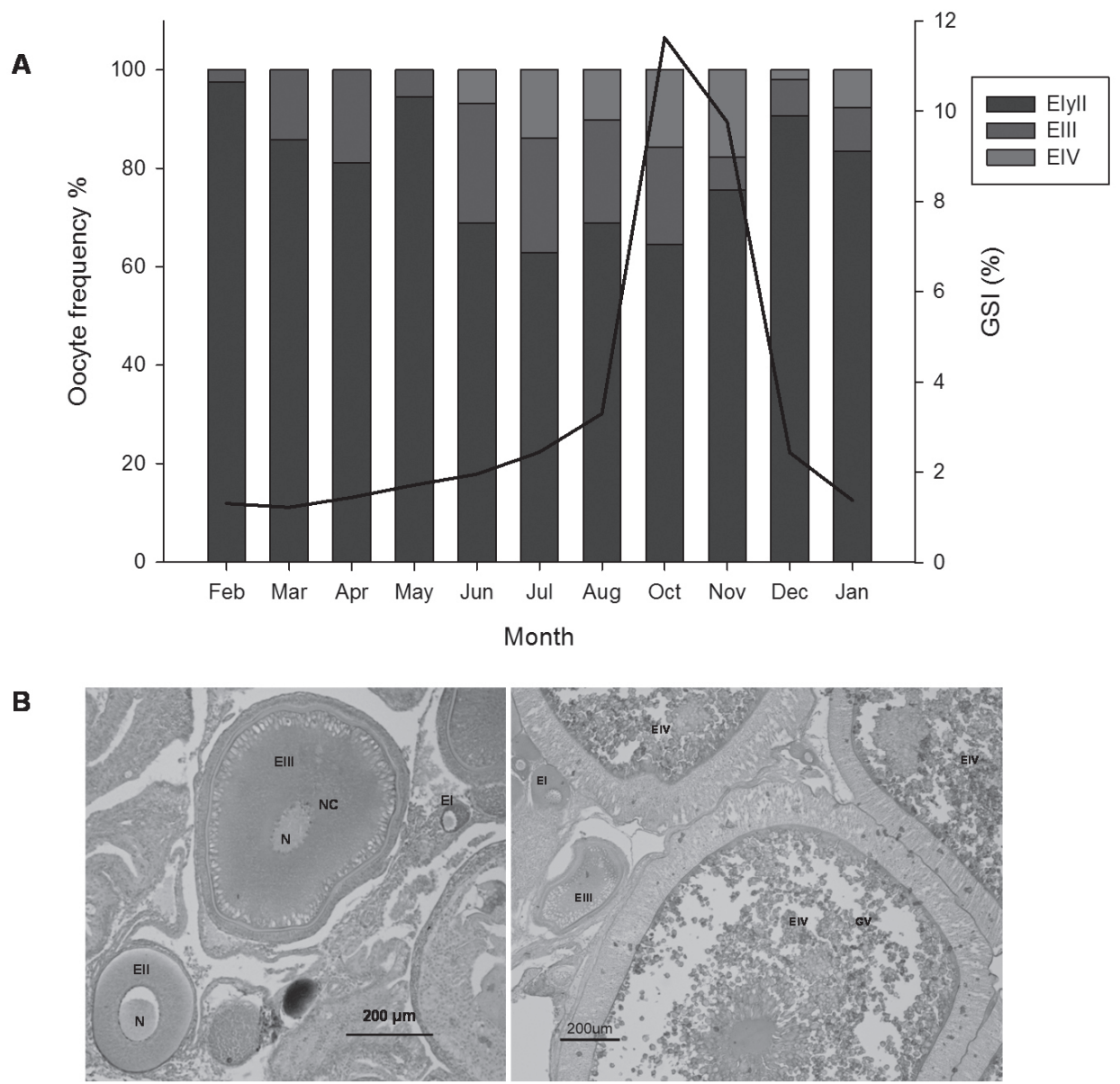

FiguRE 2. A) Seasonal oocyte maturation states for Trichomycterus areolatus. EI: oocyte stage I, EII: oocyte stage II, EIV: oocyte stage IV (according to Huaquin et al. 2002); Black line represents mean GSI for each month (modified from Chiang et al. (2011a). B) Photomicrographs of transverse sections of ovaries from T. areolatus; EI \& EII: primary oocytes, EIII: previtelogenic oocytes, EIV: mature oocytes, GV: yolk granules, N: nucleus, NC. nucleolus.

FIGURA 2. A) Estados de maduración estacional de los oocitos para Trichomycterus areolatus. EI: oocito en estado I, EII: oocito en estado II, EIV: oocito en estado IV (modificado de Huaquin et al. 2002); Línea negra representa el promedio de IGS para cada mes (modificado de Chiang et al. 2011a). B) Fotomicrografías de secciones transversales de los ovaries de T. areolatus; EI \& EII: oocitos primarios, EIII: oocitos previtelogénicos, EIV: oocitos maduros, GV: gránulos de vitelo, N: núcleo, NC: nucléolo. 


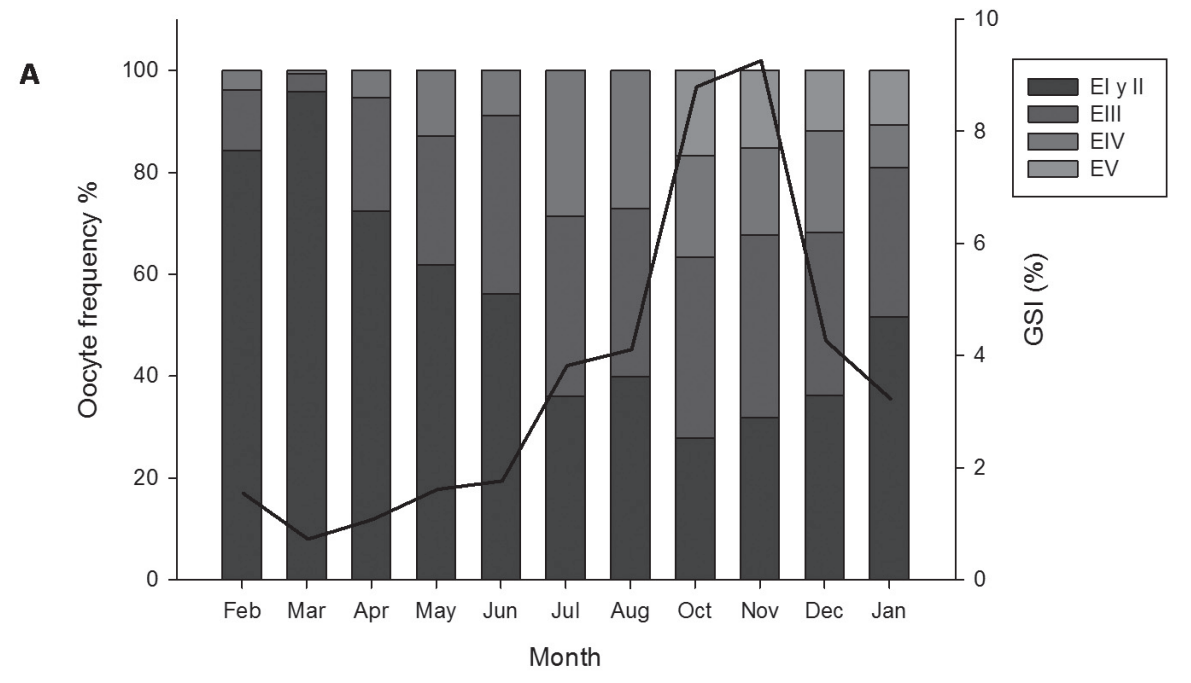

B
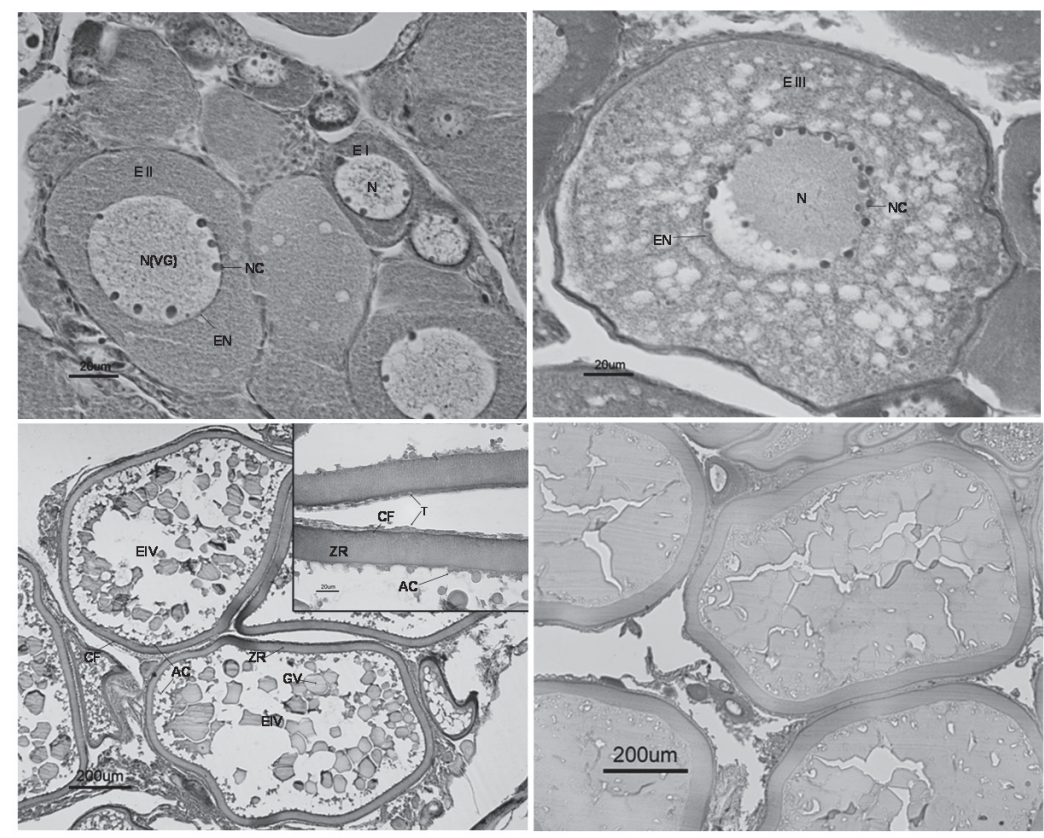

FIgURE 3. A) Seasonal oocyte maturation states for Percilia gillissi. EI: oocyte stage I, EII: oocyte stage II, EIV: oocyte stage IV, EV: oocyte stage V (modified from Quiroz 2006; Ancalaf 2008); Black line represents mean GSI for each month modified (from Chiang et al. (2011a) B) Photomicrographs of transverse sections of female gonads of P. gillissi; EI \& EII: primary oocytes, EIII: previtelogenic oocytes, EIV: oocytes in vitellogenic state; EV: mature oocytes; PV: yolk platelets, ZR: zona radiata, EN: nuclear envelope, N: nucleus, NC. nucleolus, AC: cortical alveolus.

Figura 3. A) Estados de maduración estacional de los oocitos para Percilia gillissi. EI: oocito en estado I, EII: oocito en estado II, EIV: oocito en estado IV, EV: oocito en estado V (modificado de Quiroz 2006; Ancalaf 2008); Línea negra representa el promedio de IGS para cada mes (modificado de Chiang et al. 2011a). B) Fotomicrografías de secciones transversales de las gónadas femeninas de P. gillissi; EI \& EII: oocito primario, EIII: oocitos secundario, EIV: oocito en estado vitelogénico; EV: oocoto maduro; PV: plaquetas de vitelo, ZR: zona radiata, EN: envoltura nuclear, N: núcleo, NC. nucléolo, AC: alveolo cortical. 


\section{Percilia gillissi}

The populations of $P$. gillissi contained smaller individuals from December to February, intermediate sizes between March and August and increased total length in October and November $\left(\mathrm{F}=12.098_{(10)}, \mathrm{p}<0.001\right.$, Fig 4B). Smaller size frequencies were observed in December with an increase in total length of the population towards spring (OctNov), but two cohorts were not clearly seen throughout the study period (Fig. 4B). Juveniles (individuals $<43 \mathrm{~mm}$ ) showed a significant increase in length starting in June, while adults $(>43 \mathrm{~mm}$ ) showed smaller sizes between January and February $\left(\mathrm{F}=12.098_{(10)}, \mathrm{p}<0.001\right.$, Fig 4B). Growth was faster in juveniles with $\mathrm{K}$ values almost 1.6 fold higher than individuals with gonads sexually mature $\left(0.56>0.33 \mathrm{~mm} \mathrm{month}^{-1}\right)$. The $\mathrm{K}$ values of juveniles was $>1.9$ times higher than those calculated for the whole population size distribution throughout the year $(0.29$ mm month ${ }^{-1}$ ) (Table 2).
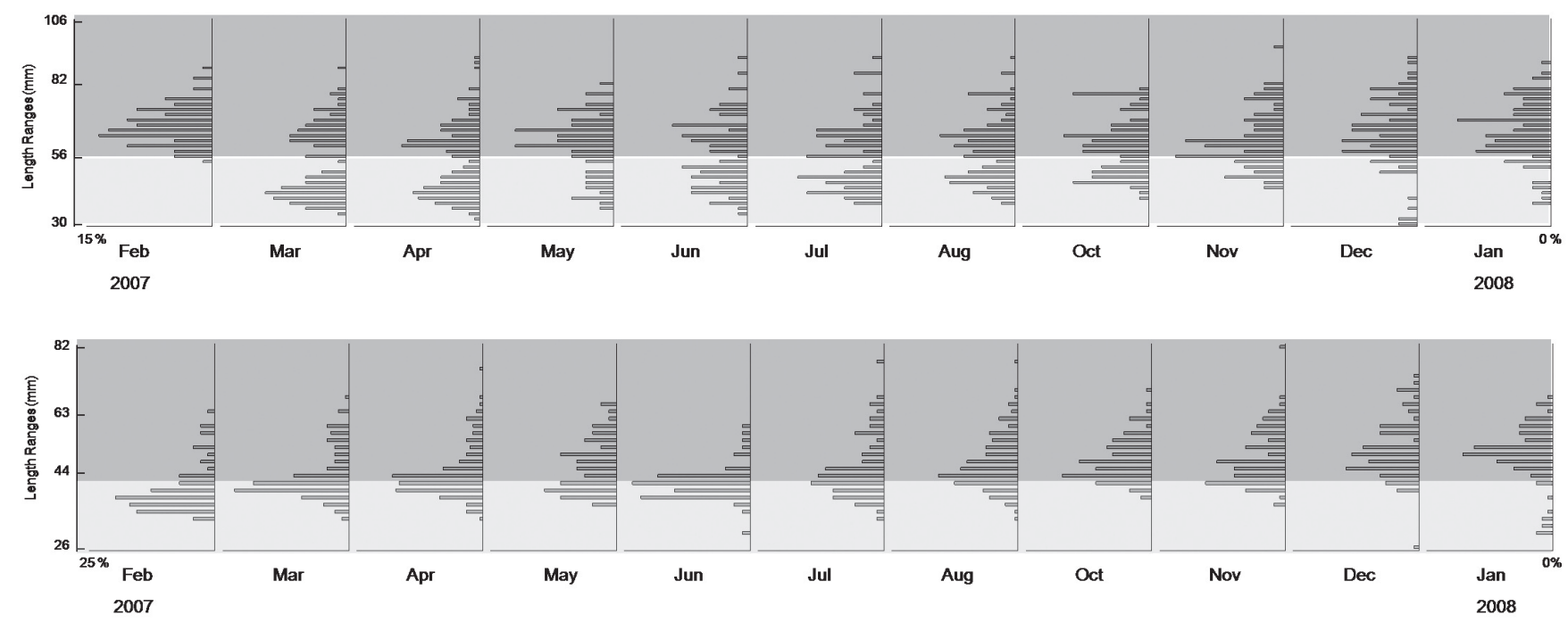

FiguRE 4. Seasonal population size distribution structure (total length) for A) Trichomycterus areolatus and B) Percilia gillissi (February 2007-January 2008). Dark area indicates sexually active individuals, light area indicates juveniles.

Figura 4. Distribución estacional de tallas de la población (largo total) para A) Trichomycterus areolatus y B) Percilia gillissi (Febrero 2007-Enero 2008). Área oscura indica individuos sexualmente activos, área clara indica juveniles.

TABle 2. Comparative growth coefficients $\left(\mathrm{K} \mathrm{mm} \mathrm{month}^{-1}\right)$ calculated by ELEFAN I K-value scan routine for Percilia gillissi and Trichomycterus areolatus in the Itata river.

TABLA 2. Comparación de coeficientes de crecimiento $\left(\mathrm{K} \mathrm{mm} \mathrm{mes}^{-1}\right)$ calculados a partis de la rutina de exploración de valores-K ELEFAN I para Percilia gillissi y Trichomycterus areolatus en el rio Itata.

\begin{tabular}{lcccc}
\hline SPecie & StaRting Length $(\mathbf{m m})$ & L $\infty(\mathbf{m m})$ & $\begin{array}{c}\text { ELEFAN I } \\
\text { K (mm month }\end{array}$ & Score \\
\hline Trichomycterus areolatus & 33 & 54 & 0.38 & 0.124 \\
& 54 & 99 & 0.15 & 0.152 \\
& 33 & 99 & 0.29 & 0.159 \\
Percilia gillissi & 25 & 43 & 0.56 & 0.108 \\
& 43 & 81 & 0.29 & 0.169 \\
& 25 & 81 & 0.33 & 0.188 \\
\hline
\end{tabular}


Seasonal gonad development, growth and size structure dynamics of two freshwater fish from Chile: GuSTAVo CHIANG ET AL.

\section{DISCUSSION}

Basic biological data from freshwater fish species in Chile is scarce, with one of the major gaps in knowledge, information about spawning seasons, fecundity, reproduction strategies and growth (Habit et al. 2006). Incorporating histological data will help to understand gonadal development and when spawning events occur, and integrating this reproductive data with growth information will help us to understand population dynamics to make better decisions about fisheries management and conservation (LowerreBarbieri et al. 2011). This knowledge may also help to plan environmental management by separating natural variability from anthropogenic impacts (Chiang et al. 2011a, 2011b).

The presence of mature oocytes in the gonad of both species simultaneously with oocytes at all other different developmental stages indicates a multiple spawning reproductive strategy with continuous preparation of the gonad for development and maturation of oocytes in groups (batches) (Galloway \& Munkittrick 2006), that are spawned over a period of time in a few or many events as described for other species (Barrett \& Munkittrick 2010). The highest observed abundance of oocytes in advanced stages of maturity, were consistent with data of highest gonadosomatic indices (GSI) during spring and early summer, previously reported for both species (Chiang et al. 2011a) and to the presence of mature female (external examination) between September and December (T. areolatus) (Montoya et al. 2012). The histological analysis of the oocytes in T. areolatus is protracted from what has been reported by Manríquez et al. (1988) using macroscopic observations, which describes this species with a synchronous development of batches of oocytes in the gonad between spring and early summer. Histology allows us to clearly differentiate the stages of maturity of the gonad (Galloway \& Munkittrick 2006), as we identified mature eggs from July to January, demonstrating a long spawning season and supported by Montoya et al. (2012) that found spawned eggs of P. gillissi between November and January; while for T. areolatus they found no eggs (maybe because, siluriform eggs are mainly demersal, Huaquin et al. 2002) they described larvae and postlarvae/juveniles stages along late spring to early autum in other river systems.

The long spawning seasons for both species; a period from October to January for Percilia gillissi and from June to January for Trichomycterus areolatus, may explain the long period of recruitment of juveniles for both species. The size limit distinction between juvenile and adult fishes was determined using the initiation of reproductive development as the presence of mature oocytes (Nikolsky 1963, fide Manriquez et al. 1988; Jackobsen et al 2009) and for $T$. areolatus only fishes $\geq 50 \mathrm{~mm}$ were found with maturing gonads (Manriquez et al., 1988; Chiang et al., 2011a), while mature oocytes in $P$. gillissi started at size $\geq$ $43 \mathrm{~mm}$, as described in previous studies by external gonadal examination (Chiang et al. 2011a) and confirmed in this study by histological analysis. During our collections, no $T$. areolatus $<29 \mathrm{~mm}$ total length or $<26 \mathrm{~mm}$ total length for $P$. gillissi were captured. The absence of smaller individuals throughout the study may be due to the collections being focused on a single habitat or the use of nets of mesh size 6 $\mathrm{mm}$, for which smaller juveniles could escape. Manríquez et al. (1988) and Arratia (1983) described juveniles sized under $10 \mathrm{~mm}$, with juveniles carrying yolk sacs up to 7.6 $\mathrm{mm}$ in total length (Arratia 1983). Despite the absence of juvenile T. areolatus below $29 \mathrm{~mm}$, the presence of juveniles throughout the sampling period is consistent with the results of Manríquez et al. (1988), Arratia (1983) and Habit et al. (2003). They described a greater abundance of juveniles in March-April, together with the presence of two cohorts during this period, oocytes at different stages of maturity indicating a long spawning period for $T$. areolatus, and a recruitment period that clearly begins in late summer.

There were no reproductive or growth data for $P$. gillissi and only limited data for the closely related $P$ irwinii (Habit $\&$ Belk 2007). The populations of $P$. gillissi consisted of smaller size classes during the summer period, followed by increased growth in terms of length, to a maximum length in the spring. Juvenile fish were sporadically observed throughout the study period, with greater abundances occurring following the completion of spawning (FebruaryMarch). Through our observations of increased growth in the size of populations of $P$. gillissi, the increased abundance of young following spawning and the presence of mature oocytes for a reduced period of time, we estimate that the spawning season for this species is shorter than that observed in $T$. areolatus. Populations of both species demonstrated a temporally diverse size structure, which is indicative of a healthy environment (Aedo et al. 2009). The calculated $\mathrm{K}$ values could be showing an energy investment in fast growth within the first year of life to the size of sexual maturity and a shift of energy investment to gonad development and reproduction. This life strategy ensures successful reproductive investment and maintenance of fish populations.

This study showed that $P$. gillissi and $T$. areolatus have an extended spawning season with a multiple spawning reproductive strategy (spring to early summer and winter for $P$. gillissi late summer to early winter for $T$. areolatus), as well as shifts in energy investment from growth to gonad development during the first year of life. The results of this research confirmed the seasonality and variability of reproductive parameters evaluated previously (Chiang et al. 2011a). Multiple spawning fish species such as the two 
studied here should be collected prior to the initiation of the first spawning event (spring for P. gillissi), in order to estimate reproductive status of wild populations, before any oocytes have been released, otherwise fecundity will be underestimated (Murua et al. 2003). Histological data helped us to clarify the higher variability in GSI for $T$. areolatus identified in previous study, during the gonadal development season (October-November) due to the protracted spawning season of the larger adults (Chiang et al. 2011a). These larger fish have mature eggs and presumably start spawning in the middle of the winter prior to smaller adults. For monitoring purposes, collections should be made prior to spring for these species as the large adults initiated spawning early, increasing variability in GSI during earlier proposed monitoring seasons (Chiang et al. 2011a). This information is key to designing effective biological monitoring programs, which allows us to assess threats and understand the possible causes of deterioration of the populations exposed to stressors of different origins and help in the restoration and/or protection of these species (Galloway \& Munkittrick 2006).

\section{REFERENCES}

Aedo, J. R., Belk, M.C. \& Habit, E.M. 2009. Geographic variation in age, growth and size structure of Percilia irwini from south-central Chile. Journal of Fish Biology 74: 278-284.

Ancalaf, A.A. 2008. Caracterización del ciclo ovárico de Percilia gillissi (Giirard, 1854) capturados en la cuenca del río Itata, VII región, Chile. Seminario de Título. Universidad de Concepción. Concepción, Chile.

Arratia, G. 1981. Varasichthys ariasi n. gen. et sp. from de Upper Jurassic of Chile (Pisces: Teleostei, Varasichthyidae n. fam). Paleontographica 175: 107-139.

Arratia, G. 1983. Preferencias de habitat de peces siluriformes de aguas continentales de Chile (Fam. Diplomystidae y Trichomycteridae). Studies on Neotropical Fauna and Environment 18(4): 217-237.

Arratia, G., Rojas, G. \& Chang, A. 1981. Géneros de peces de aguas continentales de Chile. Museo Nacional de Historia Natural Publicacion Ocas 34: 3-108.

Barrett, T.J. \& Munkittrick, K.R. 2010. Seasonal reproductive patterns and recommended sampling times for sentinel fish species used in environmental effects monitoring programs in Canada. Environmental Reviews 18:115-135.

Campos, H., Alay, F., Ruiz, V.H. \& Gavilán, J.F. 1993. Antecedentes biológicos de la fauna íctica presente en la hoya hidrográfica del río Biobío. Seminario Limnología y Evaluación de Impacto Ambiental, Universidad de Concepción, Centro de Ciencias Ambientales EULA-Chile, Centro EULAChile. 100 pp.

Chiang, G., SaAvedra, M.F., Tucca, F., Munkittrick, K.R., McMaster, M.E., Urrutia, R., Tetreault, G. \& Barra R. 2011a. Seasonal changes in reproductive endpoints in Trichomycterus areolatus (Siluriformes: Trichomycteridae) and Percilia gillissi (Perciformes, Perciliidae), and the consequences for environmental monitoring. Studies on Neotropical Fauna and Environment 46(3): 185-196.

Chiang, G., McMaster, M.E., Urrutia, R., SaAvedra, M.F., Gavilán, J.F., Tucca, F., Barra, R. \& MunkitTrick, K.R. 2011b. Health status of native fish (Percilia gillissi and Trichomycterus areolatus) downstream of the discharge of effluent from a tertiary-treated Elemental Chorine Free (ECF) pulp mill in Chile. Environmental Toxicology and Chemistry 30(8): 1793-1809.

DGA 2004. Diagnostico y clasificación de los cursos y cuerpos de agua según objetivos de calidad: Cuenca del río Itata. Santiago (Chile). Dirección General de Aguas. (Available at: www.sinia.cl/1292/articles-31018_Itata.pdf).

Duarte, W., Feito, R., Jara, C., Moreno, C. \& Orellana, E. 1971. Ictiofauna del sistema hidrográfico del río Maipo. Boletín del Museo Nacional de Historia Natural 32: 227-268.

Dussaillant, A., 2009. Hidrología de la Cuenca del río Itata. En: La cuenca Hidrográfica del río Itata, aportes científicos para su gestión sustentable. (Eds. Parra, O., Castilla, J.C., Romero, H., Quiñones R. \& A. Camaño), pp 27-44. Editorial Universidad de Concepción, Concepción, Chile.

Dyer, B.S. 2000. Revisión sistemática biogeográfica de los peces dulceacuícolas de Chile. Estudios Oceanologicos 19: 77-98.

Galloway, B. J. \& Munkittrick, K.R. 2006. Influence of seasonal changes in relative liver size, condition, relative gonad size and variability in ovarian development in multiple spawning fish species used in environmental monitoring programmes. Journal of Fish Biology 69(6): 1788-1806.

Habit, E., Bertrán, C., Arévalo, S. \& Victoriano P. 1998. Benthonic fauna of the Itata river and irrigation canals (Chile). Irrigation Science 18: 91-99.

Habit, E., Belk, M.C., Tuckfield, C. \& Parra O. 2006. Response of the fish community to human-induced changes in the Biobío River in Chile. Freshwater Biology 51: 1-11.

Habit, E., Victoriano, P. \& Campos, H. 2005. Ecología trófica y aspectos reproductivos de Trichomycterus areolatus (Pisces, Trichomycteridae) en ambientes lóticos artificiales. Revista de Biologia Tropical 53(1-2): 195-210.

Habit, E., Dyer, B.S. \& Vila, I. 2006. Estado de conocimiento de los peces dulceacuícolas de Chile. Gayana 70(1): 100113.

Habit, E. \& Belk M.C. 2007. Threatened fishes of the world: Percilia irwini Eigenmann, 1927 (Perciliidae). Environmental Biology of Fishes 78: 213-214.

Habit, H. \& Ortiz, N. 2009. Composición, distribución y conservación de los peces de agua dulce de la cuenca del río Itata. En: La cuenca Hidrográfica del río Itata, aportes científicos para su gestión sustentable. (Eds. Parra, O., Castilla, J.C., Romero, H., Quiñones R. \& A. Camaño), pp. 127-142. Editorial Universidad de Concepción, Concepción, Chile.

Huaquin, L. G., Veliz, D. \& Arratia, G. 2002. Estudio comparativo de ovarios y cubiertas ovocitarias en peces siluriformes de aguas continentales de Chile. Gayana 66(2): 269-274.

Jakobsen, T., Fogarty, M., Megrey, B. \& Mokness, E. 2009. Fish Reproductive Biology, Implications for Assessment and Management. 1st Edn. Wiley-Blackwell publishing, Chichester, UK.100 pp.

Lowerre-Barbieri, S. K., Brown-Peterson, N.J., Murua, H., 
Seasonal gonad development, growth and size structure dynamics of two freshwater fish from Chile: GuSTAVo CHIANG ET AL.

Tomkiewicz, J., Wyanski, D.M. \& Saborido-Rey, S. 2011 Emerging Issues and Methodological Advances in Fisheries Reproductive Biology. Marine and Coastal Fisheries 3(1): 32-51.

Manríquez, A., Huaquín, L., Arellano, M. \& Arratia, G. 1988. Aspectos reproductivos de Trichomycterus areolatus Valenciennes, 1846 (Pisces: Teleostei: Siluriformes) en río Angostura, Chile. Studies on Neotropical Fauna and Environment 23(2): 89-102.

McMaster, M. E., Van Der Kraak, G.J., Portt, C.B., Munkittrick, K.R., Sibley, P.K., Simth, I.R. \& Dixon, D.G. 1991. Changes in hepatic mixed-function oxigenase (MFO) activity, plasma steroid levels and age at maturity of a white sucker population (Catostomus commersoni) exposed to bleached kraft pulp mill effluent. Aquatic Toxicology 21: 199-218.

Montoya, G., Jara, A., Solis-Lufi, K., Colin, N. \& Habit, E. 2012. First stages of the life cycle in native fish from the San Pedro River (Valdivia River Basin, Chile). Gayana Especial: 86-100.

Munkittrick, K. R., Arens, C.J., Lowell, R.B. \& Kaminski, G.P. 2009. A review of potential methods of determining critical effect size for designing environmental monitoring programs. Environmental Toxicology and Chemistry 28(7): 1361-1371.

Munkittrick, K. R., McMaster M.E., Portt C.B., Van Der Kraak G.J., Smith, I.R. \& Dixon, D.G. 1992. Changes in maturity, plasma sex steroid levels, hepatic mixed function oxygenase activity, and presence of external lesions in lake white sucker (Coregonus clupeaformis) exposed to bleached kraft mill effluent. Canadian Journal of Fisheries and Aquatic Sciences 49: 1560-1569.

Murua H., Kraus G., Saborido-Rey F., Witthames P.R., Thorsen A. \& Junquera S. 2003. Procedure to estimate fecundity of marine fish species in relation to their reproductive strategy. Journal of Northwest Atlantic Fishery Science 33: 33-54.
Parrott, J. L., Wood, C.S., Boutot, P. \& Dunn, S. 2004. Changes in growth, secondary sex characteristics, and reproduction of fathead minnows exposed for a life cycle to bleached sulfite mill effluent. Journal of Toxicology and Environmental Health A-Current Issues 67(20-22): 1755-1764.

Pauly, D. \& Morgan, G.R. 1987. Length-based methods in fisheries research. ICLARM Conference Proceedings 13, 468 pp. International Center for Living Aquatic Resources Management, manila, Philippines, and Kuwait Institute for Scientific Research, Safat, Kuwait. 468 pp.

RuIz, VH. 1994. Ictiofauna del río Andalién (Concepción, Chile). Gayana Zool. 57: 109-278.

Ruiz, V.H. \& Berra, T. M. 1994. Fishes of the high Biobío river of South-Central Chile with notes on diet and speculations on the origin of the ichthyofauna. Ichthyological Exploration of Freshwaters 5(1): 5-18.

RuIZ, V.H. \& Marchant, M. 2004. Ictiofauna de aguas continentales Chilenas. Concepción (Chile).Universidad de Concepción. $356 \mathrm{pp}$.

Van Der Kraak, G. J, Munkittrick, K.R., McMaster, M.E., Portt, C.B. \& Chang, J.P. 1992. Exposure to bleached kraft pulp-mill effluent disrupts the pituitary-gonadal axis of white sucker at multiple sites. Toxicology and Applied Pharmacology 115(2): 224-233.

Vila, I., Fuentes, L.S. \& SaAvedra, M. 1999. Ictiofauna en los sistemas límnicos de la Isla Grande, Tierra del Fuego, Chile. Revista Chilena de Historia Natural 72: 273-284.

Yeom, D.H. \& Adams, S.M. 2007. Assessing effects of stress across levels of biological organization using an aquatic ecosystem health index. Ecotoxicology and Environmental Safety 67: 286-295.

Zunino, S., Baeza, M. Quiroz, S. \& Rivera, R. 1999. Ampliación distribucional de la carmelita, Percilia gillissi Girard, 1854 (Pisces: Perciilidae). Anales del Museo de Historia Natural de Valparaíso 24: 119-120.

Recibido: 22.03 .12

Aceptado: 18.06 .12 